\title{
The influence of the mother tuber on growth and tuberization of potatoes
}

\author{
K. B. A. Bodlaender and J. Marinus \\ Institute for Biological and Chemical Research on Field Crops and Herbage (IBS), \\ Wageningen, the Netherlands
}

Received 18 July 1969

\section{Summary}

Sprouts separated from mother tubers showed under certain conditions (late variety Alpha under LD) good foliage growth comparable with that of plants with a mother tuber; under other conditions (early variety Eersteling, SD) foliage growth produced by such sprouts was rather weak. Root development of the sprouts determined to a large degree foliage growth and tuber yield.

Experiments with Alpha showed that no direct or indirect influence of a mother tuber or inducing conditions (SD) are necessary for tuberization, indicating that tuberization is a normal phase in the development of potato plants. In these experiments plants from sprouts, cuttings of the 1st generation taken from these sproutlings and cuttings of the 2 nd generation taken from the cuttings of the 1 st generation produced tubers also under non-inducing conditions (LD).

\section{Introduction}

Madec and Perennec $(1959,1962)$ studied tuberization of sprouts without foliage, and of cuttings and entire plants with foliage.

Tuberization of sprouts on the mother tuber only occurs after a certain period of storage. Madec and Perennec concluded from this observation that tuberization can be induced without the presence of foliage, only by the influence of the mother tuber. Claver $(1956,1961)$ obtained three generations of tubers from mother tubers without foliage.

According to Madec and Perennec tuberization in cuttings can be induced by short day before or after cutting and by the influence of the mother tuber before cutting. The effect of day length on the foliage before cutting can be transmitted to the cuttings placed under non-inducing conditions (long day; see also Gregory, 1956). Tuberization in entire plants is induced by inductive conditions (short day, low temperature) or by the mother tuber. In cuttings and in entire plants under inductive conditions stem elongation has finished when tubers begin to form; in entire plants under noninductive conditions stem elongation continues during tuber growth. Montaldi and Claver (1962) also stated that the tuber-forming factor is synthesized in the mother tuber and in leaves with short days or low temperature. This induction factor can be transmitted by grafting an induced scion onto plants in non-inductive conditions. 
These investigations showed an influence of the mother tuber on growth and tuberization of the daughter plants, but in our opinion did not answer the question whether the influence of the mother tuber is necessary for tuberization under non-inducing conditions. We carried out experiments to answer this question and also to study the influence of the mother tuber on growth of the daughter plants. In Experiments 1 and 2 growth and tuber yield of plants grown from mother tubers with sprouts and plants grown from sprouts only were compared.

To minimize the possibility of induction of tuberization by the mother tuber already taking place during pre-sprouting and thus the stimulus for tuberization being present in these sprouts, we tried in Experiments 3 and 4 to diminish or exclude the effect of the mother tuber by a series of treatments: plants were grown from sprouts and from these plants cuttings were taken, repeatedly.

\section{Experiments with plants from sprouts}

In both experiments the early variety Eersteling and the late variety Alpha were used.

\section{Experiment 1}

Tubers were pre-sprouted from March 1 to June 4 (Eersteling, $17^{\circ} \mathrm{C}$, daylight elongated to 17 hours with incandescent bulbs) or June 8 (Alpha, $20^{\circ} \mathrm{C}$, natural daylight). On these dates the sprouts of the two varieties were about 5 and $4 \mathrm{~cm} \mathrm{long,} \mathrm{respec-}$ tively, and showed root initiations and small leaflets. They were then taken from the mother tubers and planted in sandy soil, together with mother tubers with sprouts. After planting two daylengths were applied : 12 hours (daylight) and 18 hours (12 hours daylight and 6 hours weak artificial light).

Sproutlings $(-\mathrm{mt})$ had much shorter stems than plants from mother tubers $(+\mathrm{mt})$, especially in SD and with Eersteling also in LD (Fig. 1). Alpha - mt plants were
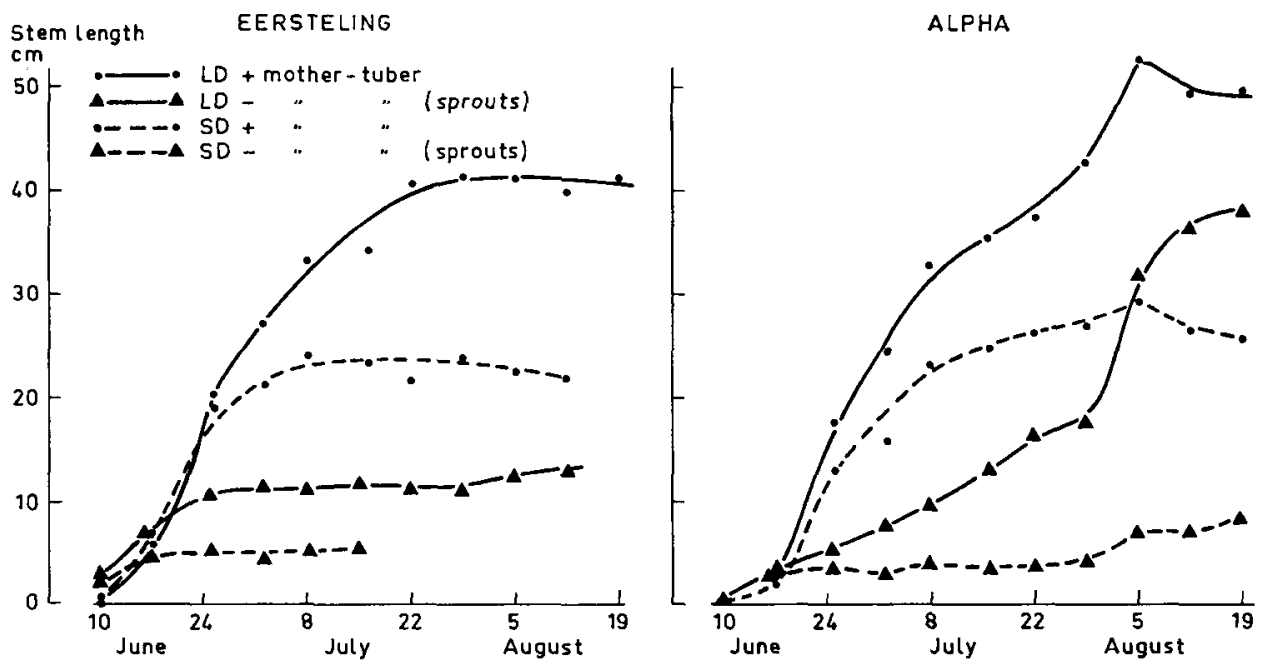

Fig. I Stem length in $\mathrm{cm}$ per plant. Plants from mother tubers and from sprouts (- sproutlings). Experiment 1. 
Table 1 Degree of senescence ${ }^{1}$. Experiment 1

\begin{tabular}{|c|c|c|c|c|c|c|c|c|c|c|c|c|}
\hline \multirow[t]{2}{*}{ Variety } & \multirow{2}{*}{$\begin{array}{c}\text { Day- } \\
\text { length }\end{array}$} & \multirow{2}{*}{$\begin{array}{c}\text { Plants } \\
\text { from }\end{array}$} & \multicolumn{10}{|c|}{ Date } \\
\hline & & & $8 / 7$ & $16 / 7$ & $22 / 7$ & $29 / 7$ & $5 / 8$ & $12 / 8$ & $19 / 8$ & $25 / 8$ & $2 / 9$ & $9 / 9$ \\
\hline Eersteling & LD & $(+m t)$ & 0 & 0 & 1 & & 1 & 1 & 3 & 6 & 9 & 10 \\
\hline , & LD & sproutlings $(-\mathrm{mt})$ & 0 & 0 & 0 & 2 & 2 & 6 & 9 & & & \\
\hline$"$ & SD & tubers $\quad(+m t)$ & 0 & 0 & 1 & 1 & 3 & 6 & 8 & & & \\
\hline$"$ & SD & sproutlings $(-m t)$ & 0 & 5 & 10 & & & & & & & \\
\hline Alpha & LD & $(+\mathrm{mt})$ & 0 & 0 & 1 & & 1 & 1 & 3 & 5 & 7 & 10 \\
\hline , & LD & sproutlings $(-m t)$ & 0 & 0 & 0 & 0 & 0 & 0 & 1 & 3 & 3 & 4 \\
\hline 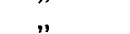 & SD & tubers $\quad(+\mathrm{mt})$ & 0 & 0 & 0 & 0 & 1 & 2 & 4 & 7 & 8 & 10 \\
\hline, & SD & sproutlings $(-\mathrm{mt})$ & 0 & 0 & 0 & 0 & 0 & 2 & 2 & 9 & 10 & \\
\hline
\end{tabular}

$10=$ all leaves green, no senescence; $10=$ plants dead

$2+\mathrm{mt}=$ with mother tuber; $-\mathrm{mt}=$ without mother tuber.

three quarters of the height of $+\mathrm{mt}$ plants in LD. Eersteling continued to lengthen longer with than without mother tuber in LD.

Eersteling $-\mathrm{mt}$ plants died earlier than $+\mathrm{mt}$ ones; Alpha - $\mathrm{mt}$ plants died slightly earlier than $+\mathrm{mt}$ ones in SD and much later than $+\mathrm{mt}$ ones in LD (Table 1).

The - mt plants produced tubers also in LD. Tuber yields of - mt plants were, however, low; only Alpha - mt plants in LD obtained a slightly reasonable tuber yield. The $+\mathrm{mt}$ plants always yielded far more tuber weight (Table 2 ).

\section{Experiment 2}

Because in the first experiment indications were found for a relation between root development and foliage growth of $-\mathrm{mt}$ and $+\mathrm{mt}$ plants, in the second experiment the influence of root formation was taken into account and a) tubers with sprouts, b) detached sprouts with roots, and c) sprouts without roots (Alpha only) were planted. The sprouts with roots were obtained by placing tubers in wet river sand some time before the planting date.

Tubers were pre-sprouted from March 29 to May 13 at $18^{\circ} \mathrm{C}$, natural daylight elongated to 18 hours with incandescent bulbs. All sprouts (with and without roots) were taken from the tubers on the planting date and planted together with the tubers with

Table 2 Tuber yield per plant. Experiment 1

\begin{tabular}{|c|c|c|c|c|c|c|}
\hline Variety & $\begin{array}{l}\text { Day- } \\
\text { length }\end{array}$ & $\begin{array}{l}\text { Plants }{ }^{1} \\
\text { from }\end{array}$ & $\begin{array}{l}\text { Lifting } \\
\text { date }\end{array}$ & $\begin{array}{c}\text { Fresh weight } \\
(g)\end{array}$ & $\begin{array}{c}\text { Dry weight } \\
(\mathrm{g})\end{array}$ & $\begin{array}{c}\text { Number of } \\
\text { tubers }\end{array}$ \\
\hline Eersteling & LD & $(+\mathrm{mt})$ & Sept. 9 & 444 & 85 & 16 \\
\hline " & LD & sproutlings $(-\mathrm{mt})$ & Aug. 23 & 12 & 3 & 1 \\
\hline 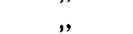 & SD & $(+m t)$ & Aug. 3 & 313 & 64 & 22 \\
\hline$"$ & SD & sproutlings $(-\mathrm{mt})$ & July 22 & 7 & 2 & 3 \\
\hline Alpha & LD & $(+\mathrm{mt})$ & Sept. 9 & 564 & 136 & 22 \\
\hline$n$ & LD & sproutlings $(-\mathrm{mt})$ & Sept. 9 & 117 & 28 & 3 \\
\hline$"$ & SD & tubers $\quad(+m t)$ & Sept. 9 & 382 & 84 & 17 \\
\hline$"$ & SD & sproutlings $(-\mathrm{mt})$ & Sept. 9 & 18 & 4 & 2 \\
\hline
\end{tabular}



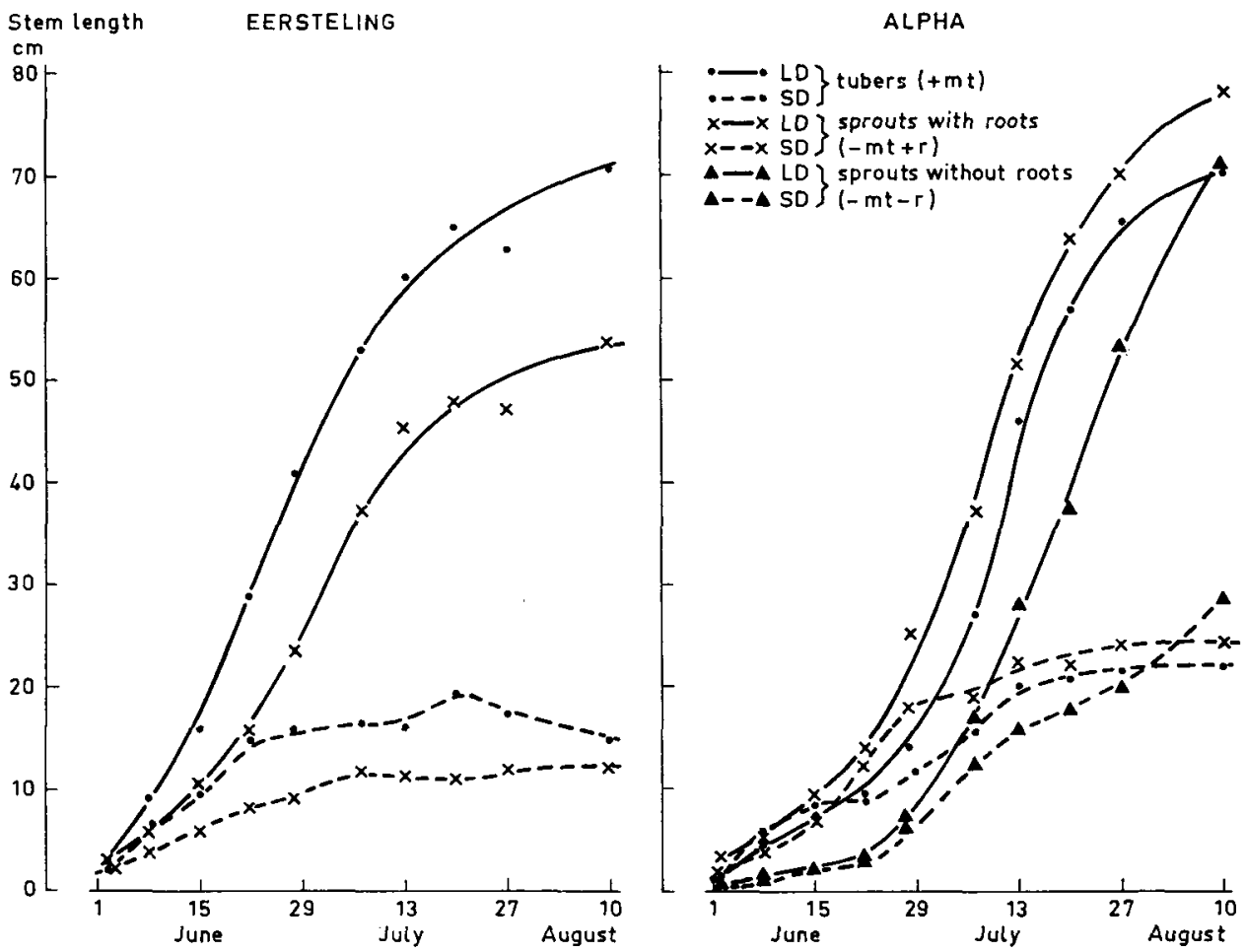

Fig. 2 Stem length in $\mathrm{cm}$ per plant. Plants from mother tubers and from sprouts (= sproutlings). Experiment 2.

sprouts $(+\mathrm{mt})$. After planting two daylengths were applied as in the first experiment. On the planting date the length of the sprouts was: Eersteling with roots $(-m t+r)$ $2-5 \mathrm{~cm}$; Alpha with roots $(-\mathrm{mt}+\mathrm{r}) 1 \frac{1}{2}-6 \mathrm{~cm}$; Alpha without roots $(-\mathrm{mt}-\mathrm{r})$ about $11 / 2 \mathrm{~cm}$.

Sprouts with roots of Eersteling produced smaller plants than tubers, but those of Alpha were slightly longer than plants with a mother tuber (Fig. 2). Sprouts of Alpha without roots produced plants showing retarded stem elongation, but these plants finally grew as long as or longer than the $+\mathrm{mt}$ plants. Moreover, these plants did not die earlier than the + mt plants.

All - mt plants formed tubers, but generally had a lower yield than the $+\mathrm{mt}$ plants (Table 3). The three groups of plants of Alpha yielded in SD about the same; in this case tuber formation and yield are mainly determined by daylength. With Alpha in LD the plants from mother tubers had a slightly higher tuber yield than the sprouts with roots; the $-\mathrm{mt}-\mathrm{r}$ plants had the lowest yields, certainly due to the retarded growth of these plants. With Eersteling in both daylengths the presence of the mother tuber simulated foliage growth and thus tuber yield was increased.

\section{Experiments with cuttings}

These experiments were carried out with the variety Alpha. 
Table 3 Tuber yield per plant. Experiment 2

\begin{tabular}{|c|c|c|c|c|c|c|}
\hline Variety & Daylength & Treatments 1 & $\begin{array}{l}\text { Lifting } \\
\text { date }\end{array}$ & $\begin{array}{c}\text { Fresh weight } \\
(g)\end{array}$ & $\begin{array}{c}\text { Dry weight } \\
(\mathrm{g})\end{array}$ & $\begin{array}{c}\text { Number of } \\
\text { tubers }\end{array}$ \\
\hline Eersteling & LD & $+m t$ & Sept. 21 & 747 & 146 & 10 \\
\hline , & LD & $-m t+r$ & Sept. 21 & 435 & 86 & 8 \\
\hline , & SD & $+\mathrm{mt}$ & Aug. 28 & 324 & 60 & 12 \\
\hline$"$ & SD & $-m t+r$ & Aug. 28 & 120 & 23 & 4 \\
\hline Alpha & LD & $+\mathrm{mt}$ & Oct. 5 & 1059 & 246 & 12 \\
\hline , & LD & $-m t+r$ & Oct. 5 & 865 & 181 & 18 \\
\hline$"$ & LD & $-\mathrm{mt}-\mathrm{r}$ & Oct. & 569 & 122 & 19 \\
\hline , & $\mathrm{SD}$ & $+m t$ & Oct. 5 & 474 & 103 & 8 \\
\hline 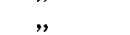 & SD & $-m t+r$ & Oct. & 497 & 103 & 19 \\
\hline$"$ & SD & $-\mathrm{mt}-\mathrm{r}$ & Oct. 5 & 463 & 99 & 14 \\
\hline
\end{tabular}

$1+\mathrm{mt}=$ with mother tuber; $-\mathrm{mt}=$ without mother tuber;

$+\mathrm{r}=$ with roots; $-\mathrm{r}=$ without roots.

\section{Experiment 3}

Tubers were pre-sprouted from Nov. 11 in the dark and after Nov. 26 under LD. On January 14 sproutlings from these tubers were planted in river sand in the glasshouse in LD (18 hours); on February 25 a part of these sproutlings were placed in SD (12 hours). On March 17 cuttings were taken from the apical part of these sproutlings and divided into 3 groups according to their degree of tuberization: without tuber initiations, with tuber initiation and with tubers (see scheme, Fig. 3). These cuttings were replanted on April 6. On April 21 a second generation of cuttings was taken from some cutting-plants of the first generation which had not yet formed tuber initiations on this day.

\begin{tabular}{llllll} 
Jan.14 Feb. 25 & March 17 & April 6 & April 21 & May 28 & June 25 \\
\hline & & I & &
\end{tabular}

sproutlings

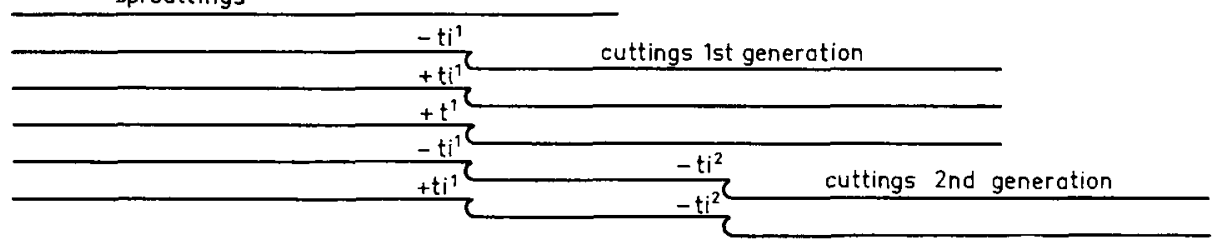

sproutlings

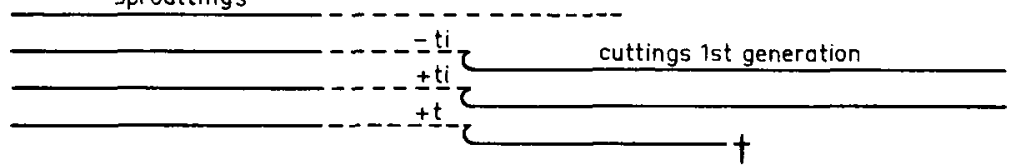

Fig. 3 Plant generations. Experiment 3. Variety Alpha. All sprouts planted on January 14 in LD. 1 and ${ }^{2}$ Tuberization of sproutlings (I) and of cuttings of the lst generation (2).

$-t i=$ without tuber initiation; $+t i=$ with tuber initiation; $+t=$ with tuber(s); + cuttings dead. $\longrightarrow=L D \quad \cdots-S D$. 


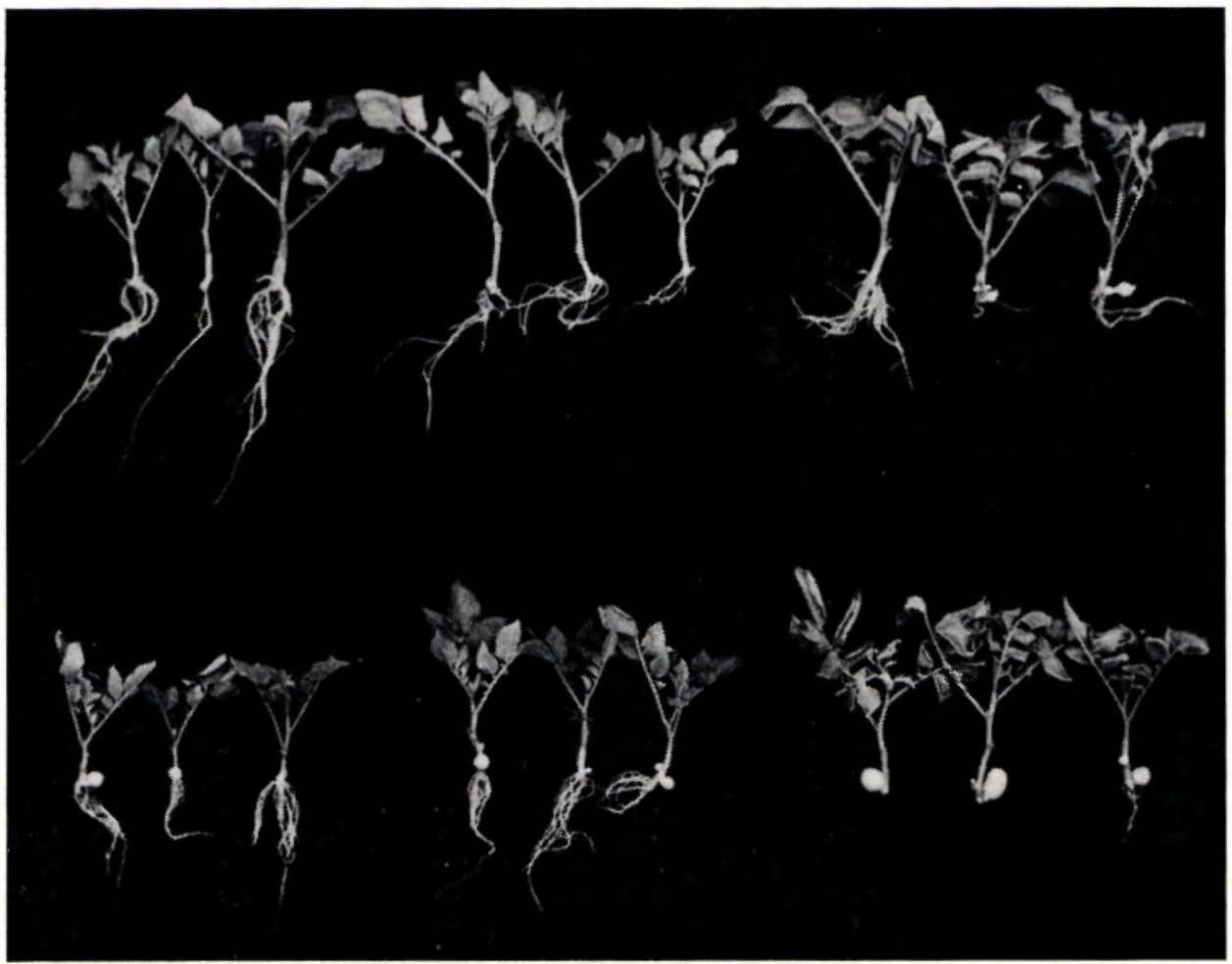

Fig. 4 Cuttings taken on March 17 from sproutlings without tuber initiations (left), with tuber initiations (centre) and with tubers (right); upper row from LD sproutlings, bottom row from $S D$ sproutlings. Photograph taken on April 6. Experiment 3.

All cuttings of both generations were grown in LD (18 hours); the temperature averaged about $16^{\circ} \mathrm{C}$. Sproutlings from which no cuttings were taken, were lifted on April 5 , the cuttings of the 1 st and 2 nd generation on May 28 and June 25, respectively; the foliage of these plants was then still quite green.

On March 17 the sproutlings were on an average 13 (LD) and 9 (SD) cm long, respectively.

The degree of tuberization of the sproutlings on March 17 influenced root development of the cuttings: on April 6 cuttings from sproutlings without tuber initiations showed generally well developed roots, those from sproutlings with tubers weak root development (see also Fig. 4). Stolon formation of the cuttings was also reversely affected by tuber formation of the sproutlings. SD during growth of sproutlings showed aftereffects: root and stolon growth and flowering were decreased on cuttings made from these sproutlings.

All cuttings developed well except those from SD sproutlings with tubers. Tuberization of the sproutlings on March 17 did not show a distinct effect on length growth of the cuttings later, but again an aftereffect of SD was visible (Table 4). Sproutlings and cuttings of both generations formed tubers under LD. When tubers were present 
Table 4 Stem length in $\mathrm{cm}$ per plant (cutting). xperiment 3

\begin{tabular}{|c|c|c|c|c|c|c|c|c|c|c|c|}
\hline \multirow{2}{*}{\multicolumn{2}{|c|}{ Cuttings lst generation }} & \multirow{2}{*}{$\begin{array}{c}\text { Tuberization } 1 \\
\text { on } 17 / 3\end{array}$} & \multicolumn{9}{|c|}{ Stem length on } \\
\hline & & & $17 / 3$ & $6 / 4$ & $13 / 4$ & $20 / 4$ & $27 / 4$ & $4 / 5$ & $11 / 5$ & $18 / 5$ & $25 / 5$ \\
\hline \multicolumn{2}{|c|}{ from LD sproutlings } & $-\mathbf{t i}$ & 3 & 6 & 7 & 11 & 21 & 26 & 33 & 37 & 39 \\
\hline , & $"$ & $+\mathrm{ti}$ & 4 & 7 & 9 & 15 & 23 & 28 & 38 & 43 & 46 \\
\hline$"$ & $"$ & $+t$ & 4 & 6 & 9 & 14 & 25 & 32 & 40 & 44 & 45 \\
\hline \multicolumn{2}{|c|}{ from SD sproutlings } & $-\mathrm{ti}$ & 1 & 3 & 3 & 5 & 8 & & 24 & 33 & 42 \\
\hline , & $"$ & $+\mathrm{ti}$ & 2 & 4 & 4 & 5 & 10 & 13 & 22 & 26 & 31 \\
\hline$"$ & " & $+\mathrm{t}$ & 4 & 5 & 5 & & & & & & \\
\hline
\end{tabular}

$\mathrm{s}-\mathrm{ti}=$ without tuber initiation(s) $+\mathrm{ti}=$ with tuber initiation(s) $+\mathrm{t}=$ with tuber(s).

on the sproutlings, the daughter cuttings tuberized more readily than when the sproutlings had not yet started tuber formation on the day of cutting (see Fig. 4 and Table 5).

\section{Experiment 4}

Tubers were pre-sprouted in the dark and later under LD; growth of sproutlings and of cuttings of two generations took place under LD. The - apical - cuttings of the 1st generation were made on March 22, when none of the sproutlings had formed any tubers or tuber initiation yet; the cuttings of the 2 nd generation were made on April 19 from cuttings of the 1st generation without tuber initiations. Cuttings of both generations produced tubers (fresh weight averaging 69 and $51 \mathrm{~g}$ per plant for the cuttings of the 1st and 2nd generation on June 15 and July 13, respectively; the foliage was still quite green on the lifting dates.

Table 5 Foliage and tuber yield per plant. Experiment 3

\begin{tabular}{|c|c|c|c|c|c|}
\hline \multirow{2}{*}{$\begin{array}{l}\text { Type of plant } \\
\text { and daylength }\end{array}$} & \multirow{2}{*}{$\begin{array}{l}\text { Tuberization } 1 \\
\text { on }\end{array}$} & \multirow{2}{*}{$\begin{array}{l}\text { Lifting } \\
\text { date }\end{array}$} & \multicolumn{2}{|c|}{ Fresh weight $(g)$} & \multirow{2}{*}{$\begin{array}{c}\text { Number of } \\
\text { tubers }\end{array}$} \\
\hline & & & foliage & tubers & \\
\hline $\begin{array}{l}\text { Sproutlings } \\
\text { LD } \\
\text { SD }\end{array}$ & & $\begin{array}{l}5 / 4 \\
5 / 4\end{array}$ & $\begin{array}{l}18 \\
17\end{array}$ & $\begin{array}{l}21 \\
28\end{array}$ & $\begin{array}{l}1 \\
2\end{array}$ \\
\hline $\begin{array}{c}\text { Cuttings } 1 \text { 1st generation } \\
\text { from LD sproutlings } \\
", \\
",\end{array}$ & $\begin{array}{l}17 / 3 \\
-\mathrm{ti} \\
+\mathrm{ti} \\
+\mathrm{t}\end{array}$ & $\begin{array}{l}28 / 5 \\
28 / 5 \\
28 / 5\end{array}$ & $\begin{array}{l}41 \\
47 \\
54\end{array}$ & $\begin{array}{l}43 \\
45 \\
71\end{array}$ & $\begin{array}{l}3 \\
5 \\
5\end{array}$ \\
\hline $\begin{array}{c}\text { from SD sproutlings } \\
,\end{array}$ & $\begin{array}{l}-t i \\
+t i\end{array}$ & $\begin{array}{l}28 / 5 \\
28 / 5\end{array}$ & $\begin{array}{l}52 \\
33\end{array}$ & $\begin{array}{l}45 \\
12\end{array}$ & $\begin{array}{l}3 \\
2\end{array}$ \\
\hline $\begin{array}{l}\text { Cuttings 2nd generation } \\
\text { from cuttings 1st gen. (LD) } \\
\text { " }\end{array}$ & $\begin{array}{l}17 / 3 \quad 21 / 4 \\
-\mathrm{ti}-\mathrm{ti} \\
+\mathrm{ti}-\mathrm{ti}\end{array}$ & $\begin{array}{l}25 / 6 \\
25 / 6\end{array}$ & $\begin{array}{l}68 \\
43\end{array}$ & $\begin{array}{l}40 \\
63\end{array}$ & $\begin{array}{l}3 \\
4\end{array}$ \\
\hline
\end{tabular}




\section{Discussion}

Presence or absence of the mother tuber influences growth and yield of potato plants. Plants from detached sprouts of Alpha under LD can grow just as well as plants with mother tubers; however, under SD and with Eersteling both under LD and SD growth of such sproutlings was rather weak. With an early variety and under SD root and foliage growth is retarded or weaker, the presence of a mother tuber promotes this growth. The favourable influence of the mother tuber on growth is under these conditions more pronounced than with Alpha under LD. The limited growth of sproutlings is largely determined by the development of roots: sprouts of Alpha with roots on the planting date showed more advanced foliage growth than sprouts without roots. Plants from sprouts without a mother tuber formed in all cases tubers, but the yield depended largely on foliage growth. Conditions decreasing root and foliage growth and hastening senescence (short day, early variety) are unfavourable for tuber yield. Sproutlings of Alpha under LD produced higher tuber yields than plants with a mother tuber in the same daylength. This demonstrates that neither short days nor a direct influence of the mother tuber is necessary for tuber growth.

It could be assumed that the stimulus for tuberization of the sproutlings was already formed during pre-sprouting and transmitted via the sprouts to the sproutlings. If present, this stimulus was diluted in a series of plant generations (sproutlings, cuttings 1st and 2 nd generation). All three plant generations produced, however, tubers under SD and LD. It can be concluded therefore that tuber formation is a normal phase in the development of potato plants; a direct or indirect influence of inducing conditions (short day) or of a mother tuber is not necessary to induce tuberization.

Tuber growth takes place under SD and LD, but SD generally accelerates the beginning of tuber growth. This influence of SD, given to plants with a mother tuber, can be transmitted to cuttings made from these plants and placed under LD (Madec and Perennec, 1959, 1962). Such a transmission of SD influence was also found from sproutlings to cuttings under $\mathrm{LD}$ : cuttings from $\mathrm{SD}$ sproutlings started tuber growth earlier than those from LD sproutlings (Experiment 3).

Madec and Perennec saw evidence for the influence of the mother tuber on tuber induction in grafting experiments: when a tomato scion was grafted onto a potato stock with a mother tuber, ample tuberization occurred on the potato stock; when grafted onto a potato stock without mother tuber hardly any tuberization occurred. According to Madec and Perennec the effect of the mother tuber before cutting can be transmitted from plants with a mother tuber to cuttings: cuttings of plants grown from tubers stored at $16-18^{\circ} \mathrm{C}$ showed earlier tuber initiation than those from tubers stored at $2-4^{\circ} \mathrm{C}$.

Our experiments show that neither mother tuber nor short days are needed for tuber induction. The results of Madec and Perennec neither indicate that a mother tuber is necessary for tuber induction. They can, however, be explained as follows: the mother tuber can promote foliage growth, and by this increased foliage growth tuberization and yield; under certain conditions the mother tuber, like short day, can accelerate tuber initiation.

\section{References}

Claver, F. K., 1956. Observaciones sobre la tuberizacion de brotes de papa y ullucus cultivados in vitro. Rev. Fac. Agron. Univ. nac. La Plata (3a epoca) 32(1) 111-122 (with English summary). 
Claver, F. K., 1961. Ensayos sobre incubacion de plantas tuberosas. Rev. Fac. Agron. nac. La Plata (3a epoca) 37(1-2) 73-95 (with English summary).

Gregory, L .E., 1956. Some factors for tuberization in the potato plant. Am. J. Bot. 43: 281-28B.

Madec, P. \& Perennec, P., 1959. Le rôle respectif du feuillage et du tubercule-mère dans la tuberisation de pa pomme de terre. Eur. Potato J. 2: 22-49.

Madec, P. \& Perennec, P., 1962. Théorie explicative de la double induction de la tubérisation de la pomme de terre par le feuillage et le tubercule-mère. Euphytica 11 (Supplement) 65-68.

Montaldi, E. R. \& Claver, F. K., 1963. Tuberization of the potato plant under non-inducing conditions. Eur. Potato J. 6: 223-226. 